\title{
School library 2.0 Towards school library 2.0
}

\author{
Carlos Pinheiro \\ Teacher librarian \\ Escola EB 2,3 Padre Alberto Neto \\ Portugal
}

\begin{abstract}
Until the beginning of the 21st century, the web was mostly a place to retrieve information. Then, around 2004, the web 2.0 new tools allowed common people, with no programming skills, to add content to the web, full of interactivity. Schools started using web 2.0 in order to reach out and engage with generation $Y$. Today web 2.0 technologies are transforming the ways in which school libraries operate and deliver their services in this fast changing online social and collaborative world.

We believe that web 2.0 tools will help us to provide authentic learning experiences for students, encouraging creativity, innovation, critical thinking and collaboration, promoting the information literacy skills that are required in the 21st century, in order to have a positive impact on student's achievement.
\end{abstract}

web 2.0 tools, school libary 2.0,social bookmarking

\section{School library 2.0}

The web 2.0 tools have redefined the learning landscape as we know it. The ways that students today communicate, interact, acquire and share information, search, investigate, and participate in the creation and re-mixing of new content, is quite different since last century and will clearly have an impact upon the school and the school library, To remain effective in the fast-moving world of technological changes, school libraries must change the way that services are delivered to users. Scholl libraries must encourage user participation in the creation of content providing to their users interactive content to reach out far beyond the library building and to engage with an increasingly community of digital learners. School library 2.0 makes information available wherever and whenever the user requires, more interactive, collaborative, and towards the needs and expectations of today's students.

\section{The web 2.0 tools in our school library}

Blog: http://lerparacrer.wordpress.com

Easy to use, easy to stay updated, an appealing look, blogs are great tools for libraries. The contents can be sorted by labels, dates, allow comments, and encourages sharing and engagement. Our school library blog provides news and announcements, presents collections of links for specific topics, supplies lists of new acquisitions, reading lists and book reviews, facilitates access to podcasts, slideshows and videos and provide library instructional 
resources. We have, since October 2007, more than 200.000 hits, lots of interaction with readers, and very positive feedback form ours sutdents

\section{Social bookmarking: http://www.diigo.com/user/biblionet}

Social bookmarking is a collaborative filtering technology that allows to reduce the quantity of information by assessing its relevance and value. Social bookmarking tools enables us to quickly collocate web resources into an annotated and tagged (subject catalogued) listing. Our social bookmarking website allows users to highlight any part of a webpage and attach sticky notes to specific highlights or to a whole page. These annotations can be kept private, shared with a group. We have more than 700 bookmarks directly related to the curriculum (grades 5 to 9 ).

\section{Social network - going where our users are: http://biblioteca21.hi5.com}

In our social network site we share links to the OPAC and to the resources of the digital school library, provide resources on information literacy, advertise library collections and services, share pictures/music/videos/virtual exhibitions and we use commenting feature to ask students to suggest books and videos for the collection.

\section{Wiki: http://netescola.wikispaces.com}

We use wikis for many different purposes: library and information skills tutorials, reading lists, book reviews, etc.

\section{Podcast}

We use podcast to promote the library and teach information literacy skills. We also provide podcasts created by others, searching, classifying and delivering podcasts from other sources.

\section{IM on the blog}

This form of online communication in the blog http://lerparacrer.wordpress.com allows realtime interaction through a computer using text. Students use it as an online helpdesk.

To achieve our vision of school library 2.0 as a powerful learning centre, we believe we should improve to reach new users and better serve current ones through improved usercentred offerings; we should become effective providers of valuable content, building the library services that our users need.

\section{References}

Bogel, G. (2006). School libraries play an active, transformational role in student learning and achievement. Evidence Based Library and Information Practice.

http://ejournals.library.ualberta.ca/index.php/EBLIP/article/view/91/168 (Consultado na Internet em 14 de Janeiro 2009).

Boyd, Danah M. \& Ellison, Nicole B. (2007). Social Network Sites: Definition, History, and Scholarship. http://jcmc.indiana.edu/vol13/issue1/boyd.ellison.html (Consultado na Internet em 14 de Janeiro 2009).

Casey, M. (2006a). Born in the biblioblogosphere. http://www.librarycrunch.com/2006/01/post 1.html (consultado na Internet em 14 de Janeiro 2009). 
Casey, M. (2006b). LibraryCrunch: bringing you a library 2.0 perspective. http://www.librarycrunch.com (Consultado na Internet em 14 de Janeiro 2009).

Crawford, W. (2006). Library 2.0 and 'Library 2.0'. Cites and Insights. http://cites.boisestate.edu/civ6i2.pdf (Consultado na Internet em 14 de Janeiro 2009).

King, David Lee (2007). Library 2.0 Ripples - Another Go at the Graph. http://www.davidleeking.com/2007/08/24/library-20-ripples-another-go-at-the-graph (Consultado na Internet em 14 de Janeiro 2009).

Lance, K., Welborn, L. \& Hamilton-Pennell, C. (1992). The Impact of Library Media Centers on Academic Achievement.

http://www.eric.ed.gov/ERICDocs/data/ericdocs2sql/content_storage_01/0000019b/80/13/74/33.pdf (Consultado na Internet em 14 de Janeiro 2009).

Maness, Jack M. (2006). Library 2.0 Theory: Web 2.0 and Its Implications for Libraries.

http://www.webology.ir/2006/v3n2/a25.html (Consultado na Internet em 14 de Janeiro 2009).

National School Boards Association (2007). Creating and connecting: Research and guidelines on online social—and educational—networking. http://www.nsba.org/site/docs/41400/41340.pdf (Consultado na Internet em 14 de Janeiro 2009).

O'Reilly, Tim (2005). What Is Web 2.0 - Design Patterns and Business Models for the Next Generation of Software. http://www.oreillynet.com/pub/a/oreilly/tim/news/2005/09/30/what-is-web-20.html (Consultado na Internet em 14 de Janeiro 2009).

Recuero, R. (2005). O capital social em redes sociais na Internet.

http://www.pucrs.br/famecos/pos/revfamecos/28/raquelrecuero.pdf (Consultado na Internet em 14 de Janeiro 2009).

Todd, Ross J. (2006). How Effective are Effective School Libraries?: Students’ Perspectives from Ohio. http://www.alia.org.au/publishing/orana/40.1/ross.todd.html (Consultado na Internet em 14 de Janeiro 2009).

University College London (2008). Information behaviour of the researcher of the future.

http://www.jisc.ac.uk/media/documents/programmes/reppres/gg final_keynote_11012008.pdf (Consultado na Internet em 14 de Janeiro 2009).

\section{Biographical Notes}

Carlos Pinheiro is school librarian (Escola EB 2,3 Padre Alberto Neto, Sintra, Portugal), and a local coordinator of the School Libraries Network Office of the Portuguese Ministry of Education, and his research interests are about the information literacy and web 2.0 in the school libraries.

\section{Statement of Originality}

This statement certifies that the paper above is based upon original research undertaken by the author and that the paper was conceived and written by the author(s) alone and has not been published elsewhere. All information and ideas from others is referenced. 